\title{
SOIL SEED BANK AND VEGETATION COMPOSITION OF TWO FEN-MEADOW STANDS IN THE NETHERLANDS
}

\author{
G. MATUS ${ }^{1}$, R. VERHAGEN ${ }^{2}$ and R. M. BEKKER ${ }^{2}$ \\ ${ }^{1}$ Dept Bot., Fac. Sci., Univ. Debrecen, H-4010 Debrecen, P.O. Box 14, Hungary; \\ E-mail:matus@tigris.klte.hu \\ ${ }^{2}$ Lab. Plant Ecology, Univ. Groningen, NL-9750 AA Haren (Gn), P.O. Box 14, The Netherlands; \\ E-mail:h.m.c.verhagen@biol.rug.nl,r.m.bekker@biol.rug.nl
}

(Received 20 September, 2000)

\begin{abstract}
Soil seed bank and aboveground vegetation of Cirsio dissecti-Molinietum, a threatened species-rich fen-meadow community, were studied in two, closely located Dutch stands. In the spring soil cores of $10 \mathrm{~cm}$ depth were drilled then subdivided into equal upper and lower segments. After concentration by washing over a fine sieve samples were spread thinly on sterilized soil and germinated in a climate chamber for 14 weeks. In the aboveground vegetation frequency of species was recorded on the same plots in summer.

A total of $95 \%$ of species germinated in 5 weeks and the same portion of individuals emerged in 10 weeks. Prolonged germination of wetland species possibly due to a limited diurnal fluctuation of temperature was found. Seed densities of the stands did not differ significantly and the seed bank was similarly dominated by a few species. Correlation between dominance ranks of species in vegetation and in seed bank was weak. Seed bank of the smaller stand contained more non fen-meadow species than the other one and dominance ranks of species in different soil depths were also less similar.

Most species had transient or short-term persistent seed banks but in Juncaceae and Ericaceae long-term persistent records were typical. The smaller stand had more persistent species but most of the species present at both stands were similarly classified. Differences between the stands can be linked to their different distances from external seed sources. A more persistent-dominated seed bank and uneven layer structure in the smaller stand could reflect the greater effect of environmental fluctuations.
\end{abstract}

Key words: Cirsio-Molinietum, depth distribution, edge effect, long-term persistent, sample concentration, short-term persistent, seedling emergence, transient

\section{INTRODUCTION}

Specific knowledge of soil seed bank characteristics of vascular plants is a crucial element in understanding life cycles, community dynamics and, in practice, planning of restoration projects. Studying soil seed banks is one of the recent highlights in restoration ecological studies (Vyvey 1986, Bakker 1989, Pfadenhauer and Maas 1987, McDonald et al. 1996, Bakker and Poschlod 1996, Csontos 2001). 
Seed bank characteristics of the NW European flora are probably among the most thoroughly studied ones. Available information concerning almost 1,200 taxa was recently summarized in a seed bank database (Thompson et al. 1997). Being, however, former studies dominated by agricultural purposes a significant majority of this database is comprised of entries on species common at arable lands or at intensively managed grasslands. In contrast there is a shortage of studies from unimproved grasslands and wetlands. Improving the number of classified seed bank records of species belonging to species-rich communities is an important challenge for the future (Thompson et al. 1997).

Cirsio dissecti-Molinietum caeruleae (Sissingh 1978) is a once widespread but recently especially threatened, low-productive, species-rich fen-meadow community. A significant part of its typical species, including many characteristic ones, were not classified into seed bank types (Bekker et al. 1998, Prins et al. 1998). Those species which have some records, usually a limited number of them, were mostly classified in related communities but not in Cirsio-Molinietum. Only a limited number of studies concerning the seed bank characteristics of this association was already published (Tallowin and Smith 1996) and few results at Dutch sites, located at the centre of the geographical range of the community, were evaluated yet (van Duren et al. 1998).

Our aim was to collect information on the ability of seed bank formation of the species typical and frequent in the community. Studying specific depth distribution and dominance in the seed bank and comparing it to the composition and dominance of vegetation could contribute to the knowledge of the distribution of seed bank types (Thompson 1993, Thomson et al. 1997). Analysis of closely located but different sized stands can also reveal whether extension of the community can play a role in site-specific variation for seed bank characteristics.

An effective way of studying soil seed banks is recording seedling emergence after sample concentration by sieving. Though it is a laborious process, its time needed is fully compensated by a significantly faster and more complete germination than in unconcentrated samples. Advantages to the method also involve reduction of space required (Ter Heerdt $e t$ al. 1996). The method proved yet to be very effective in several communities but only a limited number of studies were using this method in species-rich communities (e.g. fen-meadows) (Bekker et al. 1997). 


\section{MATERIAL AND METHODS}

\section{The community}

Cirsio-Molinietum belongs to the alliance Junco-Molinion (Zuidhoff et al. 1996). It is typical of Atlantic climatic conditions (mean January temperature $0-5{ }^{\circ} \mathrm{C}$, annual fluctuation of monthly means $13-16^{\circ} \mathrm{C}$ ) (Blackstock et al. 1998, Buck-Sorlin 1993) and is present in NW European lowlands from NW Germany, the Netherlands, Belgium, France, Wales, England and Ireland (Zijlstra 1981, Rodwell 1991, Schaminée et al. 1996). The community is confined to discharge of base-rich groundwater reaching the soil surface at least in winter and spring and leading to base saturation in the topsoil (Blackstock et al. 1998, Hayati and Proctor 1990). An analysis of abiotic conditions especially that of the hydrological systems (seasonal fluctuation of groundwater level and quality) providing appropriate site conditions was recently given by Jansen et al. (2000, 2001).

Unimproved stands of the community were integrated into traditional agricultural systems as haymaking fields or, especially in Britain, as seasonally used low intensity grazing grounds (Wheeler 1980, Blackstock et al. 1997). Even at the beginning of the 20th century Cirsio-Molinietum used to be a widespread community occupying hundreds of thousands of hectars (Zuidhoff et al. 1996), but it suffered an enormous decline during the last decades (Sissingh 1978, van Duuren and Schaminée 1992). Existing sites are typically small and fragmented. Many of them are degraded by changed hydrology (drainage, desiccation, altered ground water quality; Buck-Sorlin 1993, Smeets et al. 1980), eutrophication (mineral fertilizers, atmospheric deposition, topsoil acidification; Lamers et al. 1997) and, after cessation, by litter accumulation and invasion of fast growing grasses (Lamers et al. 1997), tall herbs (Eggloff 1983) and woody species (Boeye et al. 1999).

In the Netherlands the recent area of well-developed stands is not more than 30 ha (Schaminée et al. 1996), which is scattered at some dozens of stands. All are protected but as many of them being fragmented are threatened by further species impoverishment. Numerous stands have been degraded in the last decades (Jansen et al. 1996, Rossenaar and Streefkerk 1997) in spite of an apparently proper management. Harbouring a great number of threatened species and having a very limited extension the community attracts a special interest in nature conservation. 
Study area

Two stands of Cirsio-Molinietum in the northern part of the Netherlands were chosen for study. Both sites are parts of nature conservation areas and are managed in the traditional way with late summer (late August-September) cutting but using machinery instead of scythe. The site Wijnjeterperschar (WTS) (province of Friesland, near Wijnjewoude) positioned $35 \mathrm{~km} \mathrm{SW}$ of Groningen harbours a well preserved ca 0.4 ha $(60 \mathrm{~m} \times$ $70 \mathrm{~m}$ ) large stand of the community. Floristical and vegetational survey as well as vegetation mapping of the site was completed (Hartog 1993). At the reserve Eexterveld (EXV) (province of Drenthe, near Eext), located $25 \mathrm{~km}$ S-SE of Groningen a ca 0.06 ha sized narrow $(12-18 \mathrm{~m} \times 40 \mathrm{~m})$ stand of the community can be found. A recent survey on vegetation of the reserve is available in Klooker et al. (1999). Both sites are positioned in a fragmented landscape and are surrounded by dry Calluna vulgaris and wet Erica tetralix heathlands as well as arable fields.

\section{Sampling}

Soil seed banks were sampled in mid-late April 1999, after the natural winter stratification occurred but before spring germination commenced. A $100 \mathrm{~m}^{2}$ part of visually homogeneous vegetation was studied in both areas. Ten plots of $2 \mathrm{~m} \times 5 \mathrm{~m}$ were laid out then divided into $1 \mathrm{~m} \times 1 \mathrm{~m}$ subplots resulting in 100 replicates. One soil core of $4 \mathrm{~cm}$ diameter and $10 \mathrm{~cm}$ depth was taken from each subplot and subdivided into two layers $(0-5 \mathrm{~cm}$ and 5-10 cm). Samples originating from the same horizon of the same plot $(0.6281)$ were pooled on the spot, thus 10-10 pooled samples per layer per site were subsequently analysed.

After one to eight days' storing in dark at $4{ }^{\circ} \mathrm{C}$ samples were treated with the bulk reduction procedure according to Ter Heerdt et al. (1996). Coarse material (roots, pebbles) was removed by washing the samples over a first sieve of $4.0 \mathrm{~mm}$ mesh width. Clayey and silty components, forming the bulk of sample volume, were removed and seeds were concentrated by washing over a second fine sieve of $0.212 \mathrm{~mm}$ mesh width. Except for the tiny orchid seeds, this equipment is capable of catching all the seeds possibly present. This procedure also promoted germination by freeing seeds hidden in soil particles, slight scarification of seed coats and the removal of soluble germination inhibitors.

$30 \mathrm{~cm} \times 30 \mathrm{~cm}$ pots were filled with $4-4 \mathrm{~cm}$ of normal and steam-sterilized potting soil, and then subsequently covered by $1-2 \mathrm{~mm}$ of sterilized 
sand, respectively. Concentrated samples were spread out in pots in a very thin (1-2 mm) layer in order to facilitate light penetration. Pots were placed into a climate chamber in mid-April - early May and illuminated with fluorescent tubes for 14 weeks. Duration of light/dark periods was set to 12/12 hours with $22-23 / 16-17^{\circ} \mathrm{C}$, respectively. Water was added daily, relative humidity of the light period was about $55-60 \%$. Five control pots were also used to detect accidental seed rain during sample processing. These pots were prepared and treated in the same way but no field samples were added.

Seedlings were let to grow in germination pots until reaching a size which enabled identification. Manuals of Csapody (1968) and Muller (1978) were used. Identified seedlings were repeatedly counted then removed with a minimal disturbance of the germination medium in 1-3 weeks intervals. Seedlings of unidentified taxa were at least partly transplanted into pots containing normal soil and placed into a heated greenhouse where extra illumination was supplied at daytime when natural light proved to be insufficient. Pots with transplants staying vegetative until August 1999 (especially Carex) were transferred to the experimental garden onto open-air tables where extra water was occasionally added. Identification of these was only possible by June 2000 when transplants already set seeds.

Seed bank plots in the field were left marked in spring and used for vegetation analysis in July 1999. Vascular plants were recorded in each subplot resulting in frequency data (1-100) for each site. Further species present in a 2-3 m vicinity to the plots were also recorded. Nomenclature follows van der Meijden (1996) in taxa and Schaminée et al. (1996) in syntaxa.

\section{Data processing}

No full accuracy was achieved in distinguishing between seedlings of the species pairs Juncus effusus and J. conglomeratus, Cirsium palustre and C. $\times$ forsteri. These taxa were lumped by pair in all latter analyses. Two not fully identified seed bank taxa represented by single individuals just like a fern and an orchid species of the mature vegetation as undetectable in seed bank were excluded from later analyses. Estimated seed densities were calculated by multiplying the total number of recorded seedlings with the ratio of core surface/plot surface. One seedling found corresponded with the density of 7.96 seeds $/ \mathrm{m}^{2}$. 
Number of seedlings per plot, average number of species per plot in layers of seed bank and in vegetation were compared between sites. Normality of distribution was determined first using the Kolmogorov-Smirnov test, which was followed by testing equality of variance (F test), then depending on the results $t$-tests or Welch-tests were applied to compare means (Zar 1999).

Dominance ranks of species in the vegetation (frequency values as number of occupied subplots) and in soil layers (total number of seedlings per layer) were compared. A similar comparison was also made between soil layers in order to gain an overall picture about vertical distribution on the whole of the seed bank. Spearman rank correlation with correction for tied data (Thomas 1989, Zar 1999) was used. The tests were repeated on the first 5, 10 and 15 dominants, respectively, in order to exclude a false interpretation by choosing the level of dominance arbitrarily. When comparing dominance ranks between vegetation and seed bank the species set tested was based on the dominants of vegetation. When comparing dominance ranks between soil layers dominants of the upper layer were chosen.

Specific seed bank classification was based on the depth distribution of viable seeds. According to Thompson et al. (1997) species missing from the seed bank or present only in the surface layer were considered as having a "transient" seed bank type. Those ones more frequent in the upper layer but also present in the lower one were labelled as "short-term persistent" ones while species having an at least as high density in the lower layer than in the upper layer were considered as "long-term persistent" ones.

In order to avoid false interpretation from accidental occurrences we only classified those species that were relatively frequent in the vegetation (present in $>3$ plots) or were represented by more than three seedlings. No seed bank classification was given to the lumped taxa.

\section{RESULTS}

\section{Time needed}

Collecting soil cores in inundated spring conditions required about half to one day's field work per site by four persons, dependent on soil moisture content. Washing and spreading of samples from one site took about one and a half to two days by one person, dependent on content of organic matter. Preparing pots needed one more day per site. 
Germination started in a few days' time after sample processing. Most of the individuals (about 92-93\%) emerged in the first 10 weeks. Though germination did not stop fully it was negligible (1-2 individuals per week) after 12 weeks. Over $95 \%$ of the totally identified 57 taxa appeared within 5 weeks. No new species germinated after the 9th week (Fig. 1). Based on the species composition three periods of abundant germination were distinguished. The first and most diverse phase occurred between 0-4 weeks (starting with Asteraceae, Ranunculaceae and culminating in Poaceae). The second and biggest one took place after $5-7$ weeks with a mass germination of Juncus spp. and Carex spp. The third and smallest germination peak with Ericaceae happened after 8-11 weeks (Table 1).

Identification and first removal of seedlings was usually possible 1-2 weeks after germination. As identification skills improved removal in common species became possible as early as a few days after emergence. In case of most of the problematic taxa requiring transplantation identification took one-two months but was much longer in perennial monocotyledons (e.g. sedges) where vegetative organs provide little help. In this case, if flowering and seed set did not happen in the year of germination, altogether 12-14 months were needed.

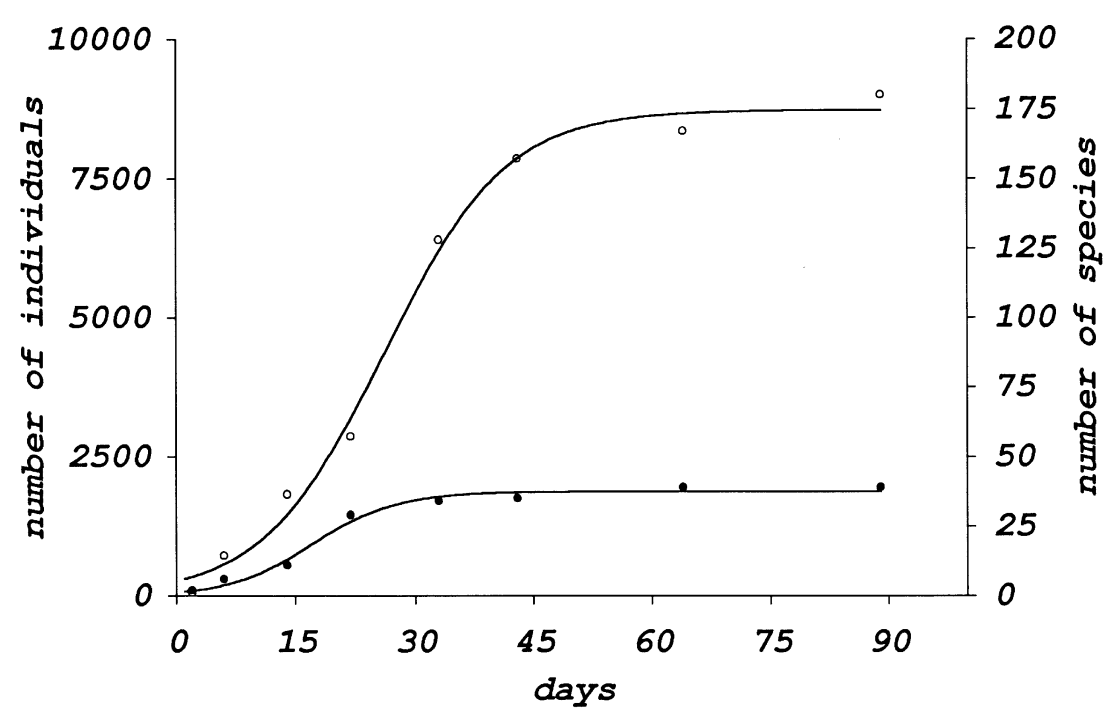

Fig. 1. Total cumulative number of individuals (open circles) and that of species (filled circles) germinated from seed bank samples of the Wijnjeterperschar. Sigmoid saturation curves were fitted using the equation: $f=a /\left(1+\exp \left(-\left(x-x_{0}\right) / b\right)\right)$. Parameters for number of individuals: $\mathrm{a}=8740.2, \mathrm{~b}=7.61, \mathrm{x}_{0}=26.13 ; \mathrm{r}^{2}=0.9940, p<0.0001$. Parameters for number of species: $\mathrm{a}=37.51, \mathrm{~b}=5.26, \mathrm{x}_{0}=17.14 ; \mathrm{r}^{2}=0.9842, p<0.0001$ 
Seed bank

A total of 8,954 seedlings were removed and identified from the Wijnjeterperschar samples, representing an estimated seed density of over 71,000 seeds $/ \mathrm{m}^{2}$. Forty-two taxa were detected out of which 37 and 34 were found in the upper and lower layers, respectively. The most common taxa were Juncus conglomeratus et effusus, J. bulbosus, J. articulatus, Agrostis canina and Ranunculus flammula. A total of 8,056 seedlings of 43 taxa emerged from the Eexterveld samples (over 64,000 seeds $/ \mathrm{m}^{2}$ ) out of which 41 and 32 originated from the upper and lower layers, respectively. The five most common taxa were Juncus conglomeratus et effusus, Erica tetralix, Ranunculus repens, Agrostis canina and Myosotis laxa subsp. cespitosa. Both seed banks were similarly dominated only by a few taxa. The five most common ones gave $88-94 \%$ of the individuals, depending on the site. A further 3-7 species contributed 3-5\%, while most of the species were rare.

Density of seeds and number of taxa decreased with soil depth. Depending on the stand the upper soil layers contained about 1.75-2.0 times more viable seeds and about 1.1-1.3 times more taxa than the lower ones (not tested statistically). In other words the upper layers contained 63-67\% of the seed population of $0-10 \mathrm{~cm}$. About $90 \%$ of the local seed bank taxa

Table 1

Approximate time requirement for mass germination in some species frequent in or typical of the seed bank of the stands. Germination in climate chamber $(12 \mathrm{~h} / 12 \mathrm{~h}$ day/night and $23 / 17^{\circ} \mathrm{C}$ ) after natural stratification

\begin{tabular}{lrllr}
\hline Species & Weeks & & Species & Weeks \\
\cline { 1 - 1 } Phase 1 & & & Potentilla erecta & $3-4$ \\
Leontodon autumnalis & $0-1$ & & Molinia caerulea & $3-5$ \\
Centaurea jacea & $0-1$ & & Anthoxanthum odoratum & 4 \\
Cirsium dissectum & $1-2$ & & Hydrocotyle vulgaris & 4 \\
Cirsium palustre & $1-2$ & & Mentha arvensis & 4 \\
Senecio aquaticus & $1-2$ & & Succisa pratensis & 4 \\
Achillea ptarmica & $2-3$ & Valeriana dioica & 4 \\
Cardamine pratensis & $2-3$ & Veronica scutellata & 4 \\
Galium palustre & $2-3$ & Danthonia decumbens & $4-6(-7)$ \\
Holcus lanatus & $2-3$ & Phase 2 & $5-7(-10)$ \\
Lotus pedunculatus & $2-3$ & Juncus effusus et conglomeratus & $(4-) 5-5(-10)$ \\
Myosotis laxa & $2-3$ & Juncus bulbosus & $5-7$ \\
Ranunculus flammula & $2-3$ & Carex spp. & $5-7(-10)$ \\
Lycopus europaeus & $2-4$ & Juncus articulatus & $7-9(-11)$ \\
Agrostis canina & $2-4(-5)$ & Juncus bufonius & \\
Ranunculus repens & $2-4(-5)$ & Phase 3 & $8-10(-12)$ \\
Betula pubescens & 3 & Erica tetralix & $9-11(-13)$
\end{tabular}


Table 2

Frequency of viable seeds (seed $\left./ \mathrm{m}^{2}\right)(\mathrm{a})$, the average number of taxa in seed bank plots $(\mathrm{b})$ and in vegetation plots and subplots (c) at Wijnjeterperschar (WTS) and Eexterveld (EXV), respectively

\begin{tabular}{|c|c|c|c|}
\hline Site & WTS & EXV & $\mathrm{P}$ \\
\hline \multicolumn{4}{|c|}{ a) viable seeds/plot/layer $(n=10)$} \\
\hline $0-5 \mathrm{~cm}$ & $573.5 \pm 111.78$ & $544.5 \pm 252.79$ & ns \\
\hline $5-10 \mathrm{~cm}$ & $321.8 \pm 53.33$ & $275.9 \pm 150.92$ & ns \\
\hline $0-10 \mathrm{~cm}$ & $895.3 \pm 154.93$ & $820.4 \pm 310.51$ & ns \\
\hline \multicolumn{4}{|c|}{ b) species number of seed bank/plot/layer $(n=10)$} \\
\hline $0-5 \mathrm{~cm}$ & $17.3 \pm 3.06$ & $22.0 \pm 2.58$ & 0.01 \\
\hline $5-10 \mathrm{~cm}$ & $13.3 \pm 2.67$ & $16.0 \pm 3.30$ & 0.1 \\
\hline $0-10 \mathrm{~cm}$ & $19.7 \pm 2.58$ & $24.7 \pm 2.71$ & 0.001 \\
\hline \multicolumn{4}{|c|}{ c) species number of vegetation } \\
\hline per plot $(n=10)$ & $27.7 \pm 4.52$ & $24.9 \pm 1.79$ & 0.1 \\
\hline per subplot $(n=100)$ & $15.74 \pm 3.23$ & $16.05 \pm 0.66$ & ns \\
\hline
\end{tabular}

were detected in the upper layer, while in the lower one, dependent on the stand, $65 \%$ and $70 \%$ were found, respectively. Both layers of Wijnjeterperschar (WTS) had slightly (5-16\%) more viable seeds than in Eexterveld (EXV), but number of seedlings/layer/plot did not differ significantly and neither did it in the pooled layers (Table $2 a$ ). In contrast, all seed bank layers proved to be significantly richer in taxa at the Eexterveld than in the Wijnjeterperschar (Table 2b).

\section{Vegetation}

There were 47 phanerogamous species recorded in Wijnjeterperschar plots and two more ones next to them. The most common species were Agrostis canina, Carex panicea, Hydrocotyle vulgaris, Juncus conglomeratus and Salix repens. Further frequent ones included Centaurea jacea s.l., Cirsium dissectum, Mentha arvensis agg., Molinia caerulea, Ranunculus flammula and $R$. repens. The Eexterveld plots harboured 39 flowering vascular plants, while five more ones were recorded in surrounding vegetation. Agrostis canina, Cirsium palustre, Juncus conglomeratus, Lotus pedunculatus, Molinia caerulea, Salix cinerea and Scutellaria galericulata were the most widespread, while Carex nigra, Cirsium dissectum, Galium palustre and Lycopus europaeus were also frequent.

Each of the stands had four taxa characteristic of the Junco-Molinion and some others of the 24 taxa common in both stands are also typical for the 
Table 3

Species composition and dominance of the aboveground vegetation and that of the seed bank. Frequency classes in vegetation: I: 1-2, II: 3-4, III: 5-6, IV: 7-8, V: 9-10 plots, e: extra species, detected adjacent to plots. Seed bank density classes: $1:<10 / \mathrm{m}^{2}, 2: 11-100 / \mathrm{m}^{2}$, 3: $101-1,000 / \mathrm{m}^{2}, 4: 1,001-10,000 / \mathrm{m}^{2}, 5: 10,000 / \mathrm{m}^{2}<$. Characteristic species to MolinioArrhenatheretea, Molinietalia and Junco-Molinion are indicated by one, two and three asterisks $\left({ }^{*}\right)$, respectively

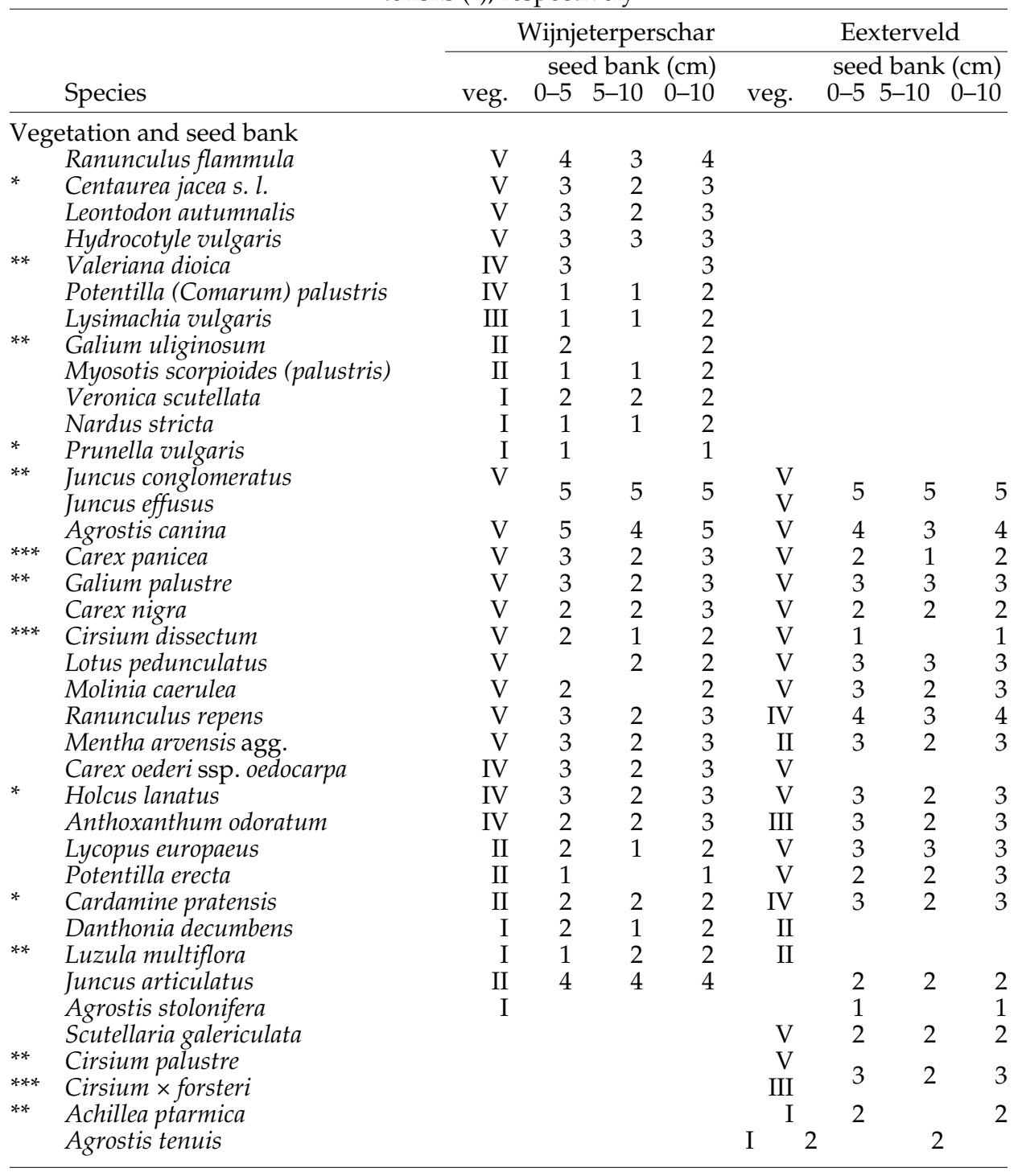


Table 3 (continued)

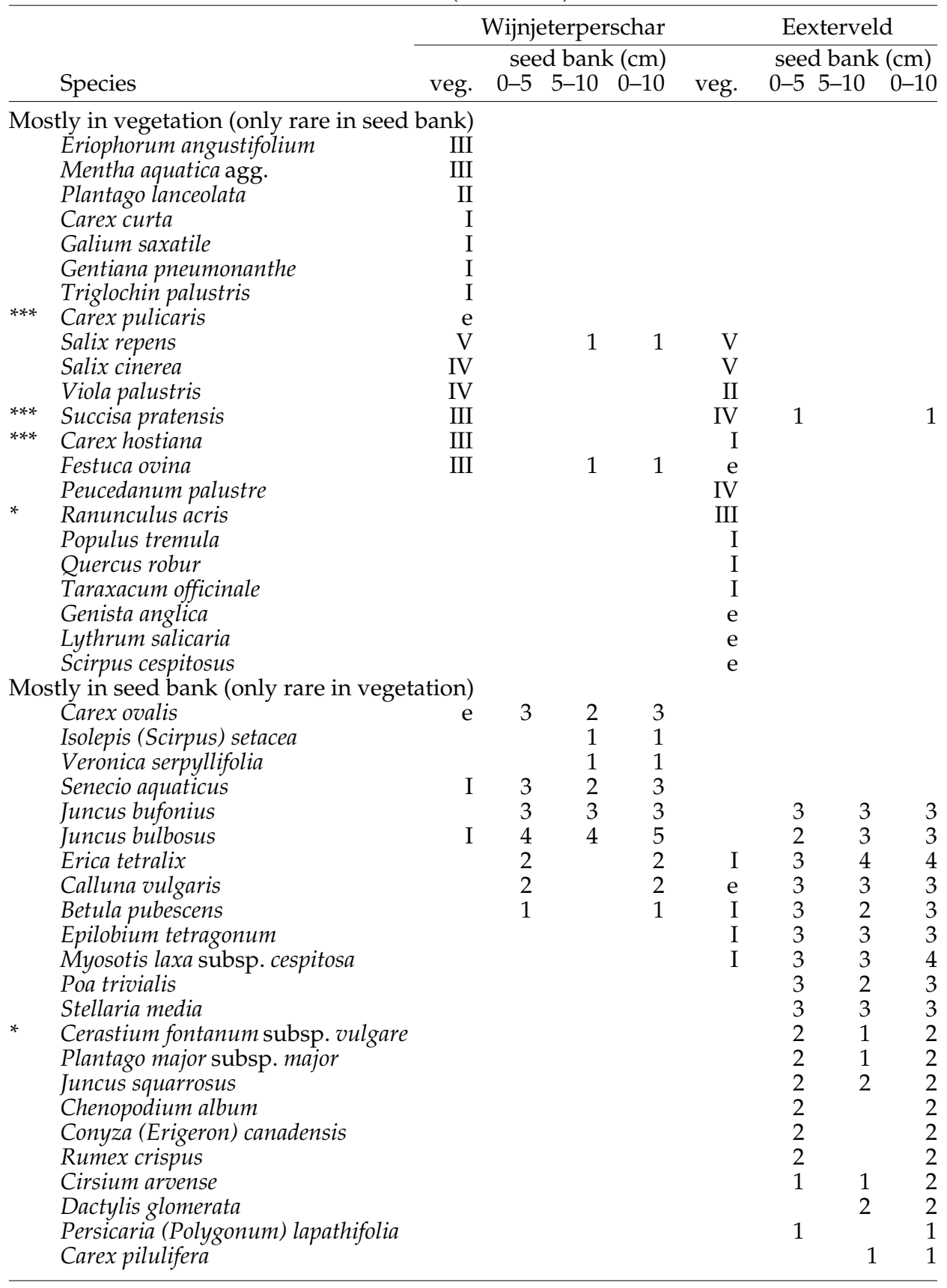


community (Zuidhoff et al. 1996). Though vegetation of the stands was evidently closely related in phytosociological terms they did differ in their species composition. The portion of species common to both sites amounted $50-60 \%$, dependent on the site. Total number of species was higher at the Wijnjeterperschar, the vegetation of which was also slightly more rich at the $10 \mathrm{~m}^{2}$ scale, but species density did not differ significantly in subplots (1 $\left.\mathrm{m}^{2}\right)$ (Table 2c).

\section{Vegetation and seed bank}

The degree of similarity of vegetation and the seed bank differed between the sites. Species common in vegetation and seed bank comprised about $65 \%$ of the local species pool in the Wijnjeterperschar but only $45 \%$ in the Eexterveld. Vegetation of the Eexterveld had less species common to its own seed bank than to the vegetation of Wijnjeterperschar. The Eexterveld had more species present only in seed bank than the other site (Table 3).

Correlation between dominance ranks of vegetation and seed bank samples was rather weak as many of the top dominants were not identical. The results were independent on which soil layer was compared to the vegetation and significance improved only slightly as the number of tested species increased (Table 4).

Species composition of local seed bank layers did not differ much but comparing dominance ranks from upper and lower soil layers resulted in divergent outcomes. Correlations of inter-layer ranks of seed bank dominants were in all cases more significant in Wijnjeterperschar than in

Table 4

Comparison of ranks of dominance in 5,10 and 15 most common species of the vegetation (frequency estimates) and ranks of seedling numbers germinated from different seed bank layers, respectively. Results of Spearman rank correlation

\begin{tabular}{ccccccc}
\hline & \multicolumn{2}{c}{$0-5 \mathrm{~cm}$} & \multicolumn{2}{c}{$5-10 \mathrm{~cm}$} & \multicolumn{2}{c}{$0-10 \mathrm{~cm}$} \\
\cline { 2 - 7 } $\mathrm{n}$ & $\mathrm{r}$ & $\mathrm{p}$ & $\mathrm{r}$ & $\mathrm{p}$ & $\mathrm{r}$ & $\mathrm{p}$ \\
\hline \multicolumn{7}{c}{ WTS seed bank layer } \\
5 & 0.2250 & $\mathrm{~ns}$ & 0.2250 & $\mathrm{~ns}$ & 0.2250 & $\mathrm{~ns}$ \\
10 & 0.2450 & $\mathrm{~ns}$ & 0.5455 & 0.1 & 0.4939 & 0.1 \\
15 & 0.4054 & 0.1 & 0.3634 & 0.1 & 0.4652 & 0.05 \\
\hline \multicolumn{7}{c}{ EXV seed bank layer } \\
5 & 0.2250 & $\mathrm{~ns}$ & 0.0750 & $\mathrm{~ns}$ & 0.0750 & $\mathrm{~ns}$ \\
10 & 0.1970 & $\mathrm{~ns}$ & -0.0091 & $\mathrm{~ns}$ & 0.1788 & $\mathrm{~ns}$ \\
15 & 0.4027 & 0.1 & 0.3295 & $\mathrm{~ns}$ & 0.4161 & 0.1 \\
\hline
\end{tabular}

ns = not significant 
Table 5

Comparison of upper $(0-5 \mathrm{~cm})$ and lower $(5-10 \mathrm{~cm})$ soil layers' seed densities on 5, 10 and 15 species dominant in the upper layer. Results of Spearman rank correlation

\begin{tabular}{ccccc}
\hline & \multicolumn{3}{c}{ WTS } & \multicolumn{3}{c}{ EXV } \\
\cline { 2 - 5 } $\mathrm{n}$ & $\mathrm{r}$ & $\mathrm{p}$ & $\mathrm{r}$ & $\mathrm{p}$ \\
\hline 5 & 0.9000 & 0.1 & 0.6000 & $\mathrm{~ns}$ \\
10 & 0.9760 & 0.001 & 0.6000 & 0.1 \\
15 & 0.8598 & 0.001 & 0.5696 & 0.05 \\
\hline
\end{tabular}

ns = not significant

Eexterveld irrespective of the number of species involved. A common trend, however, was that the power of the test increased as more species were involved (Table 5).

\section{Seed bank classification}

Seed bank classification was possible in 69 cases on 50 species. Most of the classified species, $83-93 \%$ per site, had a transient or short-term persistent seed bank. Portion of short-term persistent records was similar but in the Eexterveld there were slightly more long-term persistent ones (Table 6).

\section{DISCUSSION}

\section{Timing of germination}

Speed of germination was somewhat slower than in the original paper about the method. Ter Heerdt et al. (1996) reached 95\% of the total species number 1-2 weeks earlier and for the individuals 4-6 weeks earlier, depending on the soil type and species composition. The delay could be linked to two factors. Firstly the presence of slow germinating Ericaceae (Grime et al. 1988), missing from the relatively species poor samples of Ter Heerdt et al. (1996), has intrinsically resulted in a longer time needed. Secondly we have faced a prolonged germination in numerous species that, if

Table 6

Number of species classified into a seed bank type according to Thompson et al. (1997). T = transient, $\mathrm{S}=$ short-term persistent, $\mathrm{L}=$ long-term persistent

\begin{tabular}{ccccc}
\hline Site/species & T & S & L & Sum \\
\hline WTS & 10 & 20 & 2 & 32 \\
EXV & 10 & 21 & 6 & 37 \\
\hline
\end{tabular}


genetic differences are excluded, may have resulted from the different temperature regime of our experiment. Daily fluctuations in the climate chamber did not exceed $5-7^{\circ} \mathrm{C}$, while in greenhouse used by authors of the original paper it was $10(-23){ }^{\circ} \mathrm{C}$. A set of wetland species including Cardamine pratensis, Ranunculus repens, Juncus articulatus, J. effusus and J. conglomeratus, the latter ones forming the bulk of the seed banks in our samples, are known to be stimulated by increasing amplitude of diurnal fluctuation of temperature when germinated in presence of light (Thompson and Grime 1983).

According to Ter Heerdt et al. (1996) hand-sorting of the samples revealed that rate of germination in concentrated samples for the same period of time (14 weeks) varied between $80 \%$ and $100 \%$, depending on the species. Though, unlike in our experiment, a procedure of turning and crumbling the samples was also involved it was also proved that this additional treatment did not improve the rate of emergence and did not increase the species number significantly in concentrated samples (Ter Heerdt et al. 1996). Doubling the time needed, but being not likely to promote further germination significantly, we did not apply this method. However, a check for remaining viable seeds of yet non-germinated species by hand-sorting is a recommended but extremely time-consuming procedure.

\section{Vegetation and seed bank}

Our results on weak correlation between aboveground vegetation and soil seed bank agree with the literature. It was similarly found in geographically distant, phytosociologically different herbaceous vegetation types (Graham and Hutchings 1988, Russi et al. 1992, Virágh and Gerencsér 1988) and is likely to be a general feature in European grasslands (Bekker et al. 1997).

Bekker et al. (1998) found that most of the Junco-Molinion species in NW Europe tended to have transient or short-term persistent records. Presence of a few species with long-term persistent records was also considered as typical of this phytosociological unit. It was especially linked to genera Carex and Juncus, taxa known as having mostly persistent records (Thompson et al. 1997). In numerous species of Juncus there is already a lot of evidence for it and our finding also coincides with them. Our results, however, do not support fully seed persistence in genus Carex in general. 
More specific studies are needed to reveal specific seed bank type spectra of this species-rich genus.

The results, however should be considered cautiously as many species, including some of the now classified ones (e.g. Agrostis canina, Anthoxanthum odoratum, Holcus lanatus), are known to possess various seed bank types (Thompson et al. 1997). Further comparative studies, also in related communities of the Carpathian Basin, can reveal whether seed bank formation of the studied Molinio-Arrhenatheretea species differs in a larger geographical distance.

\section{External factors}

An important feature of the Eexterveld seed bank is its relative richness in non-fen-meadow species. Unlike at the Wijnjeterperschar species of weedy vegetation (e.g. Chenopodium album, Cirsium arvense, Conyza canadensis, Plantago major, Stellaria media) were present in the seed bank and species of heathlands (Calluna vulgaris, Erica tetralix, Juncus squarrosus) were present in much higher densities. This difference can be explained as the chance to receive a seed from outside is likely to correlate negatively with the plots distance from the possible sources. Plots of the narrow stand in the Eexterveld, unlike in the Wijnjeterperschar, bordered inevitably very closely $(2-5 \mathrm{~m})$ with wet heathlands and the possible sources of weedy species are also closer. Therefore a strong edge effect is likely to influence the seed bank of this narrow stand.

More frequent detection of persistent seed banks of typical fenmeadow species (e.g. Myosotis laxa subsp. cespitosa, Cerastium vulgatum) at the Eexterveld is also remarkable. Existence of persistent seed banks is thought to be a response that enables populations to buffer the effect of environmental fluctuations by spreading the risk in time (Harper 1977, Cavers 1983, Venable and Brown 1988). Adapting these findings we can conclude that containing more persistent species in the seed bank is a sign for more frequent environmental fluctuations (e.g. drought) in a stand's history. Similarly, accepting the way of thinking in models of Chesson (1986), demonstrating that seed bank formation is a possible way of coexistence in varying environments, we can find that uneven layer structure of the soil seed bank is reflecting periods of massive seed production of species missing from the recent vegetation (Dactylis glomerata, Poa trivialis). As the Eexterveld stand is a significantly smaller one it is likely to be more influenced by environmental fluctuations than the bigger and broader stand 
of the Wijnjeterperschar. Having, however, no detailed data we cannot judge to what extent the site history supports this assumption.

Acknowledgements - We are indebted to Prof. J. P. Bakker and Prof. J. van Andel for their useful comments and advice in all phases of the work. Comments and help in solving technical problems are acknowledged for G. Ter Heerdt and R. van Diggelen. We thankfully acknowledge the assistance of N. Wienke, D. Øien and Y. de Vries in the field as well as of W. van Hal and J. Hogendorf in the lab and greenhouse, respectively. Thanks are due to the conservation authorities for providing permission for our fieldwork. Grants of the Hungarian State Eötvös Fellowship (Ministry of Education) in 1999 and 2000 as well as funding from the János Bolyai Research Fellowship (Hungarian Academy of Sciences) supported significantly the first author's work.

\section{REFERENCES}

Bakker, J. P. (1989): Nature management by grazing and cutting. - Dordrecht, Kluwer.

Bakker, J. P. and Poschlod, P. (1996): Seed banks and seed dispersal: important topics in restoration ecology. - Acta Bot. Neerl. 45: 461-490.

Bekker, R. M., Verweij, G. L., Smith, R. E. N., Reine, R., Bakker, J. P. and Schneider, S. (1997): Soil seed banks in European grasslands: Does land use affect regeneration perspectives? - J. Appl. Ecol. 34(5): 1293-1310.

Bekker, R. M., Schaminée, J. H. J., Bakker, J. P. and Thompson, K. (1998): Seed bank characteristics of Dutch plant communities. - Acta Bot. Neerl. 47(1): 15-26.

Blackstock, T. H., Stevens, D. P. and Yeo, M. J. M. (1997): Conservation and management of Molinia and Juncus pastures in Wales, with reference to agri-environment schemes. - In: Sheldrick, R. D. (ed.): Grassland management in the environmentally sensitive areas. Occasional Symposium of the British Grassland Society, Reading. No. 32, pp. 150-159.

Blackstock, T. H., Stevens, D. P., Stevens, P. A., Mockridge, C. P. and Yeo, M. J. M. (1998): Edaphic relationships among Cirsio-Molinietum and related wet grassland communities in lowland Wales. - J. Veg. Sci. 9(3): 431-444.

Boeye, D., Verhagen, B., van Hansebroek, V. and Verheyen, R. F. (1999): Nutrient limitation in species-rich lowland fens. - J. Veg. Sci. 8: 415-424.

Buck-Sorlin, G. (1993): Ausbreitung und Rückgang der Enklischen Kratzdistel - Cirsium dissectum (L.) - in Nordwestdeutschland. - Tuxenia 13: 183-191.

Cavers, P. B. (1983): Seed demography. - Can. J. Bot. 61: 3578-3590.

Chesson, P. (1986): Environmental variation and the coexistence of species. - In: Diamond, J. and Case, T. (eds): Community Ecology. Harper and Row, New York, pp. 240-256.

Csapody, V. (1968): Keimlingbestimmungsbuch der Dikotyledonen. - Akadémiai Kiadó, Budapest.

Csontos, P. (2001): A magbank ökológia alapjai IV. Magbank típus rendszerek. - Természetvéd. Közlem. 9: 39-50.

Duren, L. van and Schaminée, J. H. J. (1992): Distribution maps of plant communities in the Netherlands: a possible framework. - Stratiotes 5: 3-14. (in Dutch) 
Duren, L. van, Strykstra, R. J., Grootjans, A. P., ter Heerdt, G. N. J. and Pegtel, D. M. (1988): A multidisciplinary evaluation of vegetation measures in a degraded Cirsio-Molinietum fen meadow. - Appl. Veg. Sci. 1: 115-130.

Eggloff, T. (1983): Der Phosphor als primär limiterender Nährstoff in Streuwiesen (Molinion). Düngungsexperiment im unteren Reusstal. - Ber. Geob. Inst. ETH. Stiftung Rübel, Zürich, 50: 119-148.

Graham, D. J. and Hutchings, M. J. (1988): Estimation on the seed bank of a chalk grassland ley established on former arable land. - J. Appl. Ecol. 25: 241-252.

Grime, J. P., Hodgson, J. G. and Hunt, R. (1988): Comparative plant ecology. - Unwin Hyman, London.

Harper, J. L. (1977): Population biology of plants. - Academic Press, London.

Hartog, P. S. (ed.) (1993): Vegetatiekartiering van enkele Friese natuurgebieden van Wijnjeterperschar tot Snitsermar. - Everts en de Vries E. A. Oecologish Advies en Onderzoeksbureau, Groningen.

Hayati, A. A. and Proctor, M. C. F. (1990): Plant distribution in relation to mineral nutrient availability and uptake on a wet-heath site in south-west England. - J. Ecol. 78: 134-151.

Jansen, A. J. M., de Graaf, M. C. C. and Roelofs, J. G. M. (1996): The restoration of species-rich heathland communities in the Netherlands. - Vegetatio 126: 73-88.

Jansen, A. J. M., Grootjans, A. P. and Jalink, H. M. (2000): Hydrology of Dutch CirsioMolinietum meadows: prospects for restoration. - Appl. Veg. Sci. 3: 51-64.

Jansen, A. J. M., Eysink, F. T. W. and Maas, C. (2001): Hydrological processes in a Cirsio-Molinietum fen meadow: implications for restoration. - Ecol. Engineering 17: $3-20$.

Klooker, J., van Diggelen, R. and Bakker, J. P. (1999): Natuurontwikkeling op minerale gronden. - Report University of Groningen, pp. 1-155. (with English summary)

Lamers, L., de Graaf, M., Bobbink, R. and Roelofs, J. (1997): Acidification and eutrophication of fen meadows (Cirsio-Molinietum vegetations). - Levende Natuur 98(7): 246-252.

Meijden, R., van der (1996): Heukel's flora van Nederland. - Wolters-Noordhoff, Groningen.

McDonald, A. W., Bakker, J. P. and Vegelin, K. (1996): Seed bank classification and its importance for restoration of species-rich flood-meadows. - J. Veg. Sci. 7: 157-164.

Muller, F. M. (1978): Seedlings of the North-Western European Lowland. A flora of seedlings. - Dr. W. Junk B. V. Publishers, The Hague, Boston.

Pfadenhauer, J. and Maas, D. (1987): Samenpotential in Niedermoorböden des Alpenvorlandes bei Grünlandnutzung underschiedlicher Intensität. - Flora 179: 85-97.

Prins, A. H., Dijkstra, G. A. and Bekker, R. M. (1998): Feasibility of target communities in a Dutch brook valley system. - Acta Bot. Neerl. 17(1): 71-88.

Rodwell, J. (1991): British plant communities, Volume 2: Mires and heaths. - Cambridge University Press, Cambridge.

Rossenaar, A. J. G. A. and Streefkerk, J. G. (1997): Restoration of a pleistocene fen meadow: Het Stelkampsveld. - Levende Natuur 98(7): 266-272.

Russi, L., Cocks, P. S. and Roberts, E. H. (1992): Seed bank dynamics in a Mediterranean grassland. - J. Appl. Ecol. 29(3): 763-771.

Schaminée, J. H. J., Stortelder, A. H. F. and Weeda, E. J. (eds) (1996): De vegetatie van Nederland. Deel 3. Plantengemeenschappen van graslanden, zomen en droge heiden. Opulus Press, Uppsala, Leiden. 
Sissingh, G. (1978): Le Cirsio-Molinietum Sissingh et de Vries (1942) 1946 dans les Pays-Bas. - In: La végétation des prairies inondables. Coll. Phytosociol. 5: 290-301.

Smeets, P. J. A. M., Werger, M. J. A. and Tevonderen, H. A. J. (1980): Vegetation changes in a moist grassland under altered water conditions. - Biol. Conserv. 18: 123-142.

Tallowin, J. R. B. and Smith, R. E. N. (1996): Management options to conserve a CirsioMolinietum and integrate its use into productive livestock systems. - Aspects Appl. Biol. 44: 203-210.

Ter Heerdt, G. N. J., Verweij, G. L., Bekker, R. M. and Bakker J. P. (1996): An improved method for seed bank analysis: seedling emergence after removing the soil by sieving. - Functional Ecology 10: 144-151.

Thomas, G. E. (1989): A note on correction for ties with Spearman's . - J. Statist. Comp. Simul. 31: 37-40.

Thompson, K. (1993): Seed persistence in soil. - In: Hendry, G. A. F. and Grime, J. P. (eds): Methods in comparative plant ecology. Chapman and Hall, London, pp. 199-202.

Thompson, K. and Grime, J. P. (1983): A comparative study of germination responses to diurnally-fluctuating temperatures. - J. Appl. Ecol. 20: 141-156.

Thompson, K, Bakker, J. P. and Bekker, R. M. (1997): The soil seed banks of North West Europe: methodology, density and longevity. - Cambridge University Press.

Venable, D. L. and Brown, J. S. (1988): The selective interactions of dispersal, dormancy and seed size as adaptations for reducing risk in variable environments. - Amer. Naturalist 131: 360-384.

Virágh, K. and Gerencsér, L. (1988): Seed bank in the soil and its role during secondary succession induced by some herbicides in a perennial grassland community. - Acta Bot. Hung. 34: 77-122.

Wheeler, B. D. (1980): Plant communities of rich-fen systems in England and Wales. III. Fen meadow, fen grassland and fen woodland communities, and contact communities. J. Ecol. 68: 761-788.

Vyvey, Q. (1986): Kiemkrachtige zaden in de bodem: betekenis voor het natuurbehoud. Biol. Jaarb. Dodonaea 54: 116-130.

Zar, J. H. (1999): Biostatistical analysis. - Prentice Hall International, London.

Zijlstra, G. (1981): Some remarks on the Cirsio-Molinietum and the Caricetum davallianae. - Proc. K. Ned. Akad. Wet., Ser. C, 84: 89-106.

Zuidhoff, A. C., Schaminée, J. H. J. and van 't Veer, R. (1996): Molinio-Arrhenatheretea. - In: Schaminée, J. H. J., Stortelder, A. H. F. and Weeda, E. J. (eds): De vegetatie van Nederland. Deel 3. Plantengemeenschappen van graslanden, zomen en droge heiden. Opulus Press, Uppsala-Leiden, pp. 163-226. 